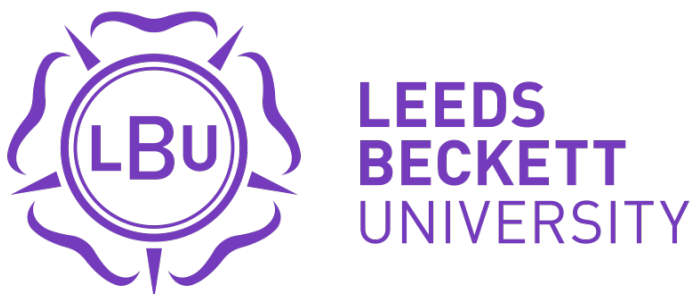

Citation:

Bradley, Q (2020) The use of direct democracy to decide housing site allocations in English neighbourhood. Housing Studies, 35 (2). pp. 333-352. ISSN 1466-1810 DOI: https://doi.org/10.1080/02673037.2019.1598548

Link to Leeds Beckett Repository record:

https://eprints.leedsbeckett.ac.uk/id/eprint/5919/

Document Version:

Article (Accepted Version)

This is an Accepted Manuscript of an article published by Taylor \& Francis in Housing Studies on 14 May 2019, available online: http://www.tandfonline.com/10.1080/02673037.2019.1598548

The aim of the Leeds Beckett Repository is to provide open access to our research, as required by funder policies and permitted by publishers and copyright law.

The Leeds Beckett repository holds a wide range of publications, each of which has been checked for copyright and the relevant embargo period has been applied by the Research Services team.

We operate on a standard take-down policy. If you are the author or publisher of an output and you would like it removed from the repository, please contact us and we will investigate on a case-by-case basis.

Each thesis in the repository has been cleared where necessary by the author for third party copyright. If you would like a thesis to be removed from the repository or believe there is an issue with copyright, please contact us on openaccess@leedsbeckett.ac.uk and we will investigate on a case-by-case basis. 


\section{The use of direct democracy to decide housing site allocations in English neighbourhoods}

By Quintin Bradley

Leeds Beckett University

School of the Built Environment and Engineering, Leeds Beckett University City Campus, The Northern Terrace, Leeds LS2 8AG, United Kingdom

Tel: +44 (0)1138121964

q.bradley@leedsbeckett.ac.uk

Bradley, Q. (2020) The use of direct democracy to decide housing site allocations in English neighbourhoods. Housing Studies, Volume 35, Issue 3.

\section{$\underline{\text { Abstract }}$}

The aim of this paper is to reclaim the democratic legitimacy of self-selecting and informed publics in citizen engagement in housing development planning. It argues for an approach to public participation in which the issues, and the articulation of conflicting attachments to those issues, are understood as the occasion for democratic politics. The paper illustrates this approach in an analysis of the use of direct democracy to decide housing allocations in the policy of neighbourhood planning in England. Drawing on literature from Science and Technology Studies and actornetwork theory, it evidences the public articulation of house-building as a matter of concern and identifies the agency of housing in enrolling publics, translating interests and in fostering debate and contention. It concludes that the articulation of conflicting interests can deepen democratic engagement in housing development planning and open up the exclusions through which this issue is currently framed.

\section{Keywords}

House building, democracy, participation, referendums, neighbourhood planning, 
$\underline{\text { Introduction }}$

In the democratic practices of housing development planning, some stakeholders are routinely excluded. Publics adversely caught up in the issue of new house-building are delegitimised on the grounds that they are motivated by individual material interest. They are judged to be unrepresentative of an ideal citizenry whose interests are subordinated to the greater good. The pursuit of an 'innocent public' (Irwin, 2006: $315)$, one that is free from attachments to the issue and attentive to instruction, accompanies the deployment of calculative technologies that close down debate and produce an inevitable consensus on the need for new homes (Metzger, Allmendinger \& Oosterlynck, 2015).

This paper redirects attention to those publics so brusquely excluded to present the issue of housing development as a public affair in which mutually exclusive interests and attachments are intertwined (Marres, 2005a). The paper argues that individual material interest is not only legitimate to, but formative of democratic participation. Contentious issues, and the attachments of citizens to those issues, are the occasion for democratic politics (Marres, 2005b). The processes of issue identification, public formation, and the articulation of conflicting attachments are constitutive of democratic participation in housing development planning (Chilvers \& Kearnes, 2016b). By following the public articulation of house-building as a 'matter of concern' (Latour, 2005a: 23), the paper seeks to identify the agency of issues in democratic practice, and their role in enrolling publics and translating interests, and in fostering deliberation and debate (Callon, 1986).

This constructivist approach is applied to a case study of participation in housing development in England and the use of direct democracy to make decisions over site allocations in the policy of neighbourhood planning. The analysis points to the productive effect of material interests in assembling a public and articulating conflicting attachments and it draws on findings from a national programme of 
research with neighbourhood planning groups carried out by the author between 2012 and 2017. It identifies three technologies of enrolment used to induce publics motivated by self-interest to acknowledge the validity of attachments that excluded their own. It demonstrates, also, how neighbourhood decisions about housing allocations remained politically contentious, and sometimes escaped attempts to manage disagreement. It portrays these findings, not as a failure of the democratic process, but as a demonstration of its success in rendering house building an issue of public debate and in expanding the space of public scrutiny. The paper points to new resolutions to the problems of housing development unveiled in the democratic debates of neighbourhood planning and it concludes that the articulation of conflicting material interests can deepen democratic engagement in housing development planning and open up the exclusions through which this debate is currently framed.

The paper seeks to contribute a fresh approach to the analysis of the engagement of citizens in planning for housing delivery and to a literature on public participation characterised by its concern with normative principles and methodologies of deliberation and agreement (Chilvers \& Longhurst, 2016; Leino \& Laine, 2011). More broadly, it seeks to add to the scholarly work of bridge-building with the field of Science and Technology Studies and the insights of actor-network theory. Its aim is to restore publics, in all their unruly selfishness and selflessness, as democratic actors in their engagement in housing development and to reorient participation in planning to the settlement of issues and not their displacement. It begins with a discussion of the practices of participation in housing development planning and introduces its approach to issue and public formation as occasions for democratic politics. The next section reviews the literature on housing allocations and neighbourhood planning and then sets out the research questions and methodology. In the three sections that follow the paper explores the definition of housing allocations as a public problem, the technologies adopted to assemble publics around a resolution to the problem, and the transformation of interests and the mobilisation of new preferences in the practices of direct democracy. The paper concludes with an assessment of an 
approach to participation in housing development planning in which the issues, and the importance of individual attachments to those issues were made central to the democratic process.

\section{Democratic legitimacy and participatory publics}

Housing development planning has a long association with public participation and an equally long-established concern with the political legitimacy of the views expressed in its decision-making processes. In the absence of traditional procedures of authorisation and accountability, citizens who actively seek participation in questions of housing supply are cast as self-selecting and suspected of seeking to circumvent the democratic process (Campbell \& Marshall, 2000; Fischel, 2004; Sturzaker, 2010). The belief that a more legitimate public exists 'in a natural state waiting to be discovered' (Chilvers \& Kearnes, 2016a: 4), provides the rationale for the exclusionary adjudication of other stakeholders as unaccountably interested in the outcome of the debate (Metzger, Soneryd \& Linke, 2017).

The assumption widely shared in the planning profession is that citizens, particularly those objecting to new housing supply, act as self-interested individuals. They lack legitimacy because they express their private interests and not wider social concerns. A quasi-scientific and derogatory nomenclature, that arose in the North American planning literature and spread across Europe and Australasia, has popularised acronyms, such as NIMBY (not in my back yard) to condemn the participation of citizens as selfish and materialistic (Dear \& Taylor, 1982; Dear, 1992; DeVerteuil, 2013). The protection of existing property values from erosion by unwelcome development appears in this literature as the prime motive for public engagement in planning decisions and finds its exemplar in resident opposition to housing growth. Set against evidence of a societal need for increased housing supply, resident objections to the allocation of sites for new homes in their community can be readily decried as the intrusion of private interests into public decision making (Sturzaker \& Shucksmith, 2011; Taylor, Cook \& Hurley, 2016; Taylor, 2013). Other studies of public 
opposition to new house building have argued that objectors often position their challenge in the context of democratic rights to be included in decisions over neighbourhood change (Cook, Taylor \& Hurley, 2013; Devine-Wright, 2009; Ellis, 2004; McClymont \& O'Hare, 2008; Wolsink, 2006). Their objections are framed on environmental, ecological and heritage grounds and they claim to speak for a manifestation of the public and to articulate public interests as 'protectors of the collective good' (Ruming, Houston \& Amati, 2012: 427). These studies cast housing objectors as representatives, speaking for, and acting for the wishes of communities (Pitkin, 1967). They suggest the presence of a stable referent; a community with political and social aspirations that can be represented (Lezaun \& Soneryd, 2007), and they significantly underplay the importance of material interest and individual attachments in democratic practice. Participation cannot be isolated from the issues at stake (Marres, 2005b).

In her influential work 'Can the subaltern speak?', the post-colonial theorist Gayatri Chakravorty Spivak (1988: 276) pointed to the distinction between representation as proxy, and representation as an act of signification. A definition of political representation as 'acting for' or 'standing for' ignores 'the constitutive dimension of representation' (Saward, 2010: 9). The idea of a constituency that can be spoken for, and a set of interests that can be represented, is a performative enactment of a specific public that accords it voice, needs and preferences. With a reference to the science laboratory, Bruno Latour (2005a: 16) describes the act of representation as a demonstration of 'an object of concern to the eyes and ears of those who have been assembled around it'. A demonstration can be a political protest or, in its scientific and technical definition, the exposition of an object and a display of its possibilities; a demonstration of what can or might be done (Barry, 2001). Participatory democracy theorist John Dewey's (1927) contention that issues call publics into being is helpful here. Publics are performed through the act of representation, which is better understood as the demonstration of an issue and what might be done about it. It is the issues, and particularly the material attachments of citizens to those issues, that drive democratic practice (Marres, 2005b). Divisive issues - matters of concern, as 
Latour (2005a: 23) called them - are at the root of democracy; they call out for debate and contestation.

This performative perspective on participation directs attention to housing as an object of concern, and one that is constitutive of publics and democratic practices (Chilvers \& Kearnes, 2016b). If issues are the occasions of democratic politics (Marres 2005a), they are also the agents of participatory practice; they enrol actors, shape the possibility of their actions, and set in progress a chain of displacement and translation through which opposing interests are articulated and reconciled (Callon 1986). Not everyone engages in political activity to represent selfless ideals, or to fulfil the obligations of citizenship to participate in democratic life. They get involved because they are adversely caught up in issues. They are hailed as democratic citizens by the issue and by their attachments to the issue (Zakhour \& Metzger, 2018). The study of issue formation, and of what happens when issues are opened up to democratic debate, returns attention to the excluded publics of participation and their opposition to housing development planning.

\section{$\underline{\text { Housing development and participation in planning }}$}

In economies predicated on financialised real estate markets, the management of public opposition to de-regulated housing development continues to vex policy makers. Public objections to new house-building pose a potential challenge to the prevailing liberalised development model and its pursuit of housing asset growth (Bramley 2018; Gallent, 2016). Where citizens are enrolled in decision-making their ability to influence the outcome is circumscribed by the deployment of calculative technologies that aim to eradicate any need for democratic debate over housing supply. Methodologies that produce unshakeably objective assessments of housing need are applied to establish targets for house-building and site allocation and ensure sufficient land is made available (Murdoch \& Abram, 2002). These calculations of projected need sit uncomfortably within a housing supply model factored on global market demand for investment property and, in the UK specifically, dominated by 
speculative private house-builders (Gallent, Durrant \& Stirling 2018). The displacement of democratic debate from the politics of this market model of housing supply has done little to disguise the controversial nature of the issue. Policy makers searching for a 'systemic fix to eliminate conflict' (Inch 2012: 532), have become increasingly attentive to the motivations of citizens opposing new house-building (Sturzaker, 2011). The introduction of neighbourhood planning in England was unusual in its attempt to elicit citizen support for house-building through an appeal to material interest. While the policy was designed to elicit acquiescence to housing allocation targets, it addressed citizens as rational actors who could, within the prescribed institutional framework, reach accord between their individual interests and societal needs (Matthews, Bramley \& Hastings, 2015).

In England in 2011 Town or Parish Councils, and in urban areas community groups established as Neighbourhood Forums, were endowed with statutory powers to formulate a development plan for their neighbourhood (Brownill \& Bradley, 2017). The primary objective of government was to enrol these communities in the allocation of sites for new housing. Neighbourhood plans were introduced as part of a new National Planning Policy Framework that made local authorities responsible for providing five years' worth of specific, developable housing sites and identifying broad locations for new housing up to nine years ahead. Neighbourhood plans had to be in general conformity with these strategic policies and 'plan positively to support local development' especially housing development (DCLG, 2012, Paragraphs 15-16). They could not promote less development than stipulated in the Local Plan or undermine its strategic policies. To win community support, the neighbourhood plan was approved by local referendum and had to receive more than 50 per cent of the vote of those registered and taking part in the ballot. Once approved, the neighbourhood plan became part of statutory development policy and was used to help determine planning applications in the locality. The political rhetoric that accompanied the launch of neighbourhood planning stressed its democratic credentials. The aim was to engage citizens not only in decisions over land-use planning but in renewed participation in the democratic process (DCLG, 2011), although the resource inequality 
intrinsic to market societies presented an obstacle to engagement in more deprived areas of the country. The policy of neighbourhood planning was described as a fundamental change in the architecture of the democratic process signalling a return to notions of citizen control popularised by Sherry Arnstein (1969) in her emblematic ladder of participation (Bradley, 2015; Brownill \& Downing, 2013). The requirement for the neighbourhood plan to secure majority support in a local referendum provided an endpoint in direct democracy and introduced a form of 'anticipatory representation' among those leading the plan (Mansbridge, 2003). They had to anticipate the preferences voters might express in the referendum and seek to assemble consensus or at least majority consent through participatory strategies (Wendling 1997). This was especially true when considering neighbourhood planning policies that might prove contentious, such as the allocation of sites for new housing. Referendums on neighbourhood plans consistently registered very high levels of support among those taking part with an average voter turnout of 39 per cent (Parker \& Wargent, 2017).

Referendums are familiar mechanisms of participatory decision-making in housing policy in Europe, where they have been used to seek approval for regeneration schemes, and their application in England, and in the wider UK, is associated with controversial estate renewal plans and with ballots of tenants over the transfer of municipal housing (Bradley, 2014). The expansion of referendums beyond constitutional affairs and outside their traditional national boundaries, has been widely perceived as a response to a crisis of legitimacy in representative democracies where formal processes of electoral accountability are increasingly seen as insufficient for resolving the tensions of a gapingly unequal society (della Porta et al, 2017). Studies of referendums suggest that the presence of direct democracy opens up debates over the issues and that referendum campaigns can be moments of opinion formation and the creation of new alignments (Lupia \& Matsusaka, 2004). Accounts of referendums on national or regional independence questions contend that the impending ballot triggers an expansion of political engagement (Qvortrup, 2015). During the Scottish referendum campaign in 2014, for example, people 'engaged 
vociferously with one another at home, in the workplace, in public spaces and...on social media' (Tierney, 2015: 226). This was a form of deliberation that was 'more rowdy, disorderly and decentred' than the consensual communication more usually imagined in the literature on public participation (Young 2001: 688), and it points to contentious issues as formative of divergent preferences and mutually exclusive interests (Mansbridge, 1996).

By the end of 2018, six years after the launch of the policy, 2,400 neighbourhood plans were under production, while 610 had been successful at referendum and become part of the statutory planning framework covering 15 per cent of England (Wargent \& Parker, 2018). Over half of all neighbourhood plans allocated specific sites for house building and all set out policies regulating the affordability, size, mix and design of new housing (Bailey, 2017). Neighbourhood planning was lauded by government for increasing the amount of land allocated for new homes, although the research base for this claim was limited (Mountain, 2015). The democratic practices of neighbourhood planning can be better understood as a demonstration of housing as an object of public concern, and as the practical demonstration of possible resolutions to that concern (Barry, 2001). The production of a neighbourhood plan for housing site allocations can be conceived as an attempt to resolve the housing question through a specific mobilisation of a democratic public. The intention of the plan is to render the object of housing an expression of public cohesion rather than dissension. Latour (2005a: 14) explains: 'We might be more connected to each other by our worries, our matters of concern, the issues we care for, than by any other set of values, opinions, attitudes or principles.' In demonstrating a potential resolution to the issue, neighbourhood plans bring a public into being around housing development as an object of debate, through the participatory practices of that debate (Marres, 2007). The next section establishes a research framework to explore this argument through an analysis of housing site allocations in neighbourhood plans.

\section{$\underline{\text { Researching democratic practice in neighbourhood planning }}$}


The aim of this study is to map the participatory processes through which the issue of housing allocations was presented in neighbourhood plans, publics were defined, and interests translated into a managed agreement or collective identity (Callon, 1986). The democratic practices under study in neighbourhood planning involve the articulation of housing supply as a political object and of the neighbourhood as a political public. These practices can be analysed across two fields of research: the association and the assembly (della Porta, 2013). The association is the neighbourhood planning group itself, usually a committee made up of volunteers and appointees, which devolves tasks to working groups, and might appoint a consultant or editorial team to write planning policy. The objects of investigation in the association are the construction of claims of meaning about housing as an issue, and the public and its attachments; the demonstration of potential resolutions to the issue; and the articulation of a cohesive identity that combines the neighbourhood and housing in one stable referent (Lezaun \& Soneryd, 2007). The assembly denotes the wider participative field and includes all those who engage in consultative events, surveys and other opportunities to comment on the neighbourhood plan, and everyone who takes part in the final referendum. Assembling a public demands action from its constituents; they are convened in consultation and actively conjured as individuals and collectives with interests and preferences. The translation of these interests into a collective identity is a work of cohesion that is just as likely to generate social difference. The objects of investigation here are the interests and attachments that are expressed, negotiated and transformed in a referendum campaign (Benhabib, 1996). Neighbourhood plans that identify sites for housing risk generating new preferences that assume collective form through the mobilising effect of the referendum (Qvortrup, 2005). The requirement for a plan to secure a majority vote through direct democracy introduces uncertainty into neighbourhood plan-making and suggests its potential to become an expansive democratic practice; one that fails to reach a resolution and instead generates new preferences on the issue (GarciaEspin et al, 2017; Pateman, 1970). 
The data for this paper comes from a programme of field research carried out across England with 300 residents in 40 neighbourhood planning groups through focus groups and interviews between 2012 and 2016 (Bradley, 2018). In addition, a desk top analysis was undertaken of 181 neighbourhood plans that were successful at referendum between May 2016 and May 2017. This analysis entailed the scrutiny of statutory statements of community engagement, draft neighbourhood plans, reports from independent examiners, the referendum version of the neighbourhood plan, and details of referendum results compiled by the local authorities. Media and social media reports of the referendums were also studied for these plans. The findings from this research were contextualised with reference to the peer reviewed literature on the decision-making practices of neighbourhood planning. Specific case studies are presented from this sample to provide situated examples of the range of democratic practices evident among neighbourhood planning groups. The plans selected for analysis are those that allocated sites for new housing and were approved at referendum. Case studies include plans whose housing allocations were challenged in legal action, and were subsequently written into case law, and those that received significantly above average, and below average participation in referendums. This selection cannot hope to convey all the variations in practice across neighbourhood plans, but it enables commonly adopted mechanisms of issue identification, public formation and the articulation of conflicting attachments to be analysed and vividly presented. It provides a study of the democratisation of planning for housing supply that evidences its situated practice, the political constructions that were articulated and the oppositions and contentions that emerged.

\section{The demonstration of housing as a matter of public concern}

'We realised that there were quite a number of land sites that had been put forward for housing in our village. Nearly every resident within the village was going to be affected by one or more of these sites and if all the sites were developed, it would double the size of the village, so there was great concern 
about this. People were collectively emotive about not wanting this development'.

The speaker is the chair of a neighbourhood planning group in Linton, a small village of 270 houses in West Yorkshire. In her narrative it was the individual attachments of residents to the issue, the proximity of new houses, and their material interest in retaining the size, and therefore the character of the village, that mobilised this public. While these interests were held individually, the issue of housing sites assembled a public as an emotive collective, displaying 'great concern' over the development and mobilised against it. Individual attachments to the issue of house-building rendered it a public issue and in turn the issue rendered a public with the potential to act collectively.

In his introduction to actor-network theory, Bruno Latour (2005b: 63) suggests that objects have agency. They can authorise, allow, afford and encourage. This is what Judith Butler called a performative agency. It works through others to bring into being certain kinds of realities (Butler, 2010). In neighbourhood planning, house building always has a specific agency. It is conceived of as a hostile force; it acts for the speculative building companies; the direction of housing is towards green fields; its assumed shape is as large uniform estates that render places indistinguishable and faceless (Bradley \& Sparling, 2017). The decision to assemble a public around a neighbourhood plan, rather than around a campaign of resistance to house building signals that it is feasible to conceive that the agency of housing supply can be changed or redirected. Housing can be separated from its figuration as 'uniform estates' and translated into an object that can contribute more beneficially to a neighbourhood.

The demonstration of house building as a matter of concern also assembles a strongwilled public with its own views on the agency of new housing and its location. The neighbourhood plan for the parish of Tattenhall, a village of around 1000 homes in Cheshire, demonstrated the threat of housing supply in 'the addition of characterless estates on the rural fringes of the village' and asserted that 'future growth based on 
large scale inappropriate development will not be supported by the community' (Tattenhall \& District, 2013: p.10). The Tattenhall neighbourhood plan reminded its public that 'the community of Tattenhall has a strong history of taking local decisionmaking into its own hands' (Tattenhall \& District, 2013: p.6), and it insisted on incremental housing growth to allow 'a vibrant and distinctive village to evolve and expand whilst retaining its unique character' (Tattenhall \& District, 2013: p.8). The plan was successful at referendum in September 2013 on a convincing 52 per cent turnout.

House building in the form of second homes and holiday homes exercised particular agency in the neighbourhood plan of St. Ives, a globally recognised holiday destination in Cornwall, with a population of 11,000 and tens of thousands of visitors every year. With external demand driving house prices up 17 times the average local salary, the agency of house building enacted a St Ives neighbourhood public with local rights and responsibilities. In its introduction to the plan the town council explained that it held 'a great responsibility to protect an internationally renowned asset' (St Ives Town Council, 2015: p.12). St Ives 'needed to be nurtured, protected and guided into the future' and 'the best people to do this are those who live here' (St Ives Town Council, 2015: p.3). This task of stewardship provided the rationale for policy interventions that introduced restrictions on all new-build to ensure homes could only be used as the owner's primary residence. The agency of housing manifested a residential public with a duty of care for St. Ives. Their housing policies were approved at referendum and subsequently upheld in the High Court where a challenge from local property agents was unsuccessful.

The plans published by neighbourhoods, and successful at referendum, represent a particular approach to housing supply as a 'matter of concern' (Latour, 2005a), one that is opposed, often explicitly, to the speculative model of volume house-building that dominates the UK development industry. In the selection of specific sites for housing, neighbourhood plans have prioritised brownfield, or previously developed, land. They promote sites that appear tailored to the preferences of small and medium 
sized building companies rather than the speculative volume builders and favour resident-led approaches to housing supply such as custom-build (Bradley \& Sparling, 2016). In their support for housing growth, they are concerned to deliver affordable homes to meet local housing need and often promote community land trusts that lock-in affordability for the future. These housing plans are referenced to characterisations of a neighbourhood or community identity, or a specific rendering of a collective public and its resolution of the housing issue (Bradley 2017; Field \& Layard 2017).

In these neighbourhood plans, housing is rendered a public issue with the agency to assemble a public with the potential to act collectively. This act of publicity is an inauguration of the neighbourhood as an 'object-oriented democracy' (Latour, 2005a: 16). The neighbourhood is conceived as a polity where the divisive matter of housing can be debated and resolved. Its public are attributed traditions of self-governance and responsibilities to provide sound guidance and stewardship. Neighbourhood planning offered a social performance of house building in which an issue of concern could be significantly reshaped, and through which housing as an object could actively participate in the production of the social, or in democracy itself. This argument can be explored further through an interview with the secretary of a neighbourhood planning group in the former mining village of Kippax, a settlement of 10,000 people near Leeds. He reflected: 'I think the impetus was not that we were concerned about housing development but that we could put ourselves in a position where we could have some control over housing development.' The demonstration of housing as a matter of public concern was a demonstration of a collective ability to resolve it. Resolution of the concern would allow the neighbourhood to take 'control of their own destiny' (East Bergholt Parish Council, 2016: 7) through 'grass-roots democracy in action' (Sherborne St. John Parish Council, 2017: 2). The occurrence of a combative democracy talk was common in the pages of neighbourhood plans and their consultation statements, as a public was manifested around its newly discovered efficacy. The neighbourhood was conceived in its housing concern as a democratic 
public, and becoming a public meant being able 'to assert a voice' (quoted in Parker, Lynn, Wargent \& Locality, 2014: 91).

A neighbourhood collective that exhibited the efficacy of self-governance was brought into being by the demonstration of housing as an issue of concern. The task of the association, or the neighbourhood plan steering group, was to translate the efficacy of its newly assembled public into a collective settlement of the housing question that they would support at referendum. The identity work done to establish a stable public is the topic of the next section.

\section{$\underline{\text { Housing allocations and stable publics }}$}

Neighbourhood plans advanced potential resolutions to the problem of housing by first defining a neighbourhood or community identity in which housing, in a particular location, or in a specific form, would find acceptance (Bradley, 2017). The collective identity set out in the neighbourhood plan was assembled by task groups, and scripted often by planning consultants, but its components were collected from a range of public engagement and participation practices. Detailed accounts of the processes of plan-making in steering groups have been provided (Brookfield, 2017; McGuinness \& Ludwig, 2017; Sturzacker \& Shaw, 2015; Vigar, Gunn \& Brooks, 2017) and methods of engagement, some of them innovations in planning participation, have been itemised (Croft et al, 2016). These engagement methods required the assemblage of a stable public that could deliberate on and accede to housing solutions. The housing question would be settled through the allocation of specific sites and not others for the location of new build, by setting boundaries to limit the scope of development, and by regulating the design, mix, and affordability of homes to be supplied. Housing, it was to be demonstrated, could be modified so that it was no longer a threat but a solution: an integral component in the evolution of a community identity and an attribute to the assemblage of a neighbourhood. Individuals were expected to consider more than their own interests, and to follow normative principles to agree what was best for the 
neighbourhood. Three technologies of enrolment were used by neighbourhood planning steering groups to displace individual interests and translate preferences into a collective identity that would suture conflicts and resolve contentions.

The first was a technology of elicitation framed to extract opinion that supported the goal of plan-making while maintaining the stability of a known public. The aim was to reduce opportunities for dissension on the issue of housing supply by narrowing engagement to selected groups and limiting the occasions for public assembly. This approach was enacted most often in neighbourhood plans conducted by formal institutions of governance, the town and parish councils whose claim to local knowledge born of residence deeded them a portrait of the neighbourhood as a knowable public with knowable concerns (Houtzager \& Lavalle, 2010). Maintaining stability meant eliciting the views of that public while preventing it from 'rising to the status of a "collective"' (Lezaun, 2007:130), whose unpredictability might overspill into new preferences over housing supply (Callon, Lascoumes \& Barthe, 2011). The adoption of a technology of elicitation was a response to statutory neighbourhood planning regulations that tightly circumscribed the opportunities to shape housing development. Where neighbourhoods were allotted specific housing targets by local planning authorities, they could not plan for any fewer homes, and where strategic sites had already been identified in their neighbourhood, they were limited to policies that could only mitigate the effect of the new housing development.

The steering group leading the neighbourhood plan for Uttoxeter, a town of 9000 in East Staffordshire, claimed to know its public and to anticipate their concerns. It was made up of '15 local people who have volunteered their time and experience... Many of the steering group have lived in the town for many years. They include members of the Town Council, members of local groups and organisations' (Uttoxeter Town Council, 2016: 2). Community engagement in the neighbourhood plan was conducted through meetings with selected residents' groups. Only two public exhibition events were held, attended by a total of 42 people and 18 feedback forms were returned. In comparison a petition started by a campaign group dedicated to the protection of 
Uttoxeter green spaces from housing development received over 3000 signatures from residents. The technology of elicitation served to refresh the claim to local knowledge made by the town council and reaffirm their portrait of a stable referent, but its failure to open up debate around housing allocations resulted in a lack of public interest in the outcome. The turnout in the referendum for the Uttoxeter Neighbourhood Plan was a low 18 per cent.

Where the claim to local knowledge by a neighbourhood planning group was founded on 'nearness' to its public (Kearns \& Parkinson, 2001), conflict over housing that over spilled from the decision-making process could contaminate the daily encounters and relationships of life in proximity (Vigar, Gunn and Brooks, 2017). The second technology, one of deliberative consensus, was applied in smaller neighbourhoods to reduce the likelihood of this outcome. This deliberative technology displaced individual interests through a number of 'obligatory passage points' to translate them into a collective agreement (Callon, 1986: 196). In the neighbourhood plan for St Minver, a parish in Cornwall of 2,400 residents, a progression of community engagement events was used to build consensus around the allocation of two new housing sites. At each event, the findings from the previous meeting were represented and collectively agreed. An initial series of public consultation meetings was attended by over 100 people and findings from these events were reported to a second public assembly. A questionnaire received 782 responses, and this was followed by a third consultation event to present the results. Another survey set out the proposals for housing development sites and a fourth public assembly attended by 200 people 'facilitated a good debate' leading to changes to the number and size of the housing sites (St. Minver Parishes, 2017: 6). At each 'passage point' the assembly were reminded of the decisions they had made and conducted through the course of action that followed from that decision, until they were ushered by their own past choices into an obligatory outcome. The St. Minver referendum registered a voter turnout of 51 per cent, and the result, with 82 per cent in favour of the neighbourhood plan and its housing sites, and 19 per cent against, demonstrated both the pursuit of consensus and the continuing articulation of dissent. 
At least five per cent of neighbourhood plans allocated more sites for housing than were required under strategic plans (Lichfields, 2018). The decision to support additional housing growth, signalled that individual immediate interests had been subordinated to collective needs, and to an expectation of future benefits. In the third, majoritarian technology of enrolment, individual interests were displaced by establishing principles of fairness as the pre-conditions of a collective identity. Having agreed to standards of procedural legitimacy in the decision-making process, the participants were then obliged to accept the outcome. The majoritarian technology of enrolment is illustrated in the neighbourhood plan for Chelveston-cum-Caldecott, a parish of only 566 people in East Northamptonshire. Here a 2-day exhibition of housing site proposals, attended by 94 out of a total of 225 households in the parish, was followed by six consultation events held to review each of the housing sites in depth. Residents were then asked to vote for the housing sites they supported in a poll; the clerk of the Parish Council acting as returning officer and 82 per cent of households participating. Seven propositions secured majority support in this way and these allocations were incorporated as housing sites into the neighbourhood plan (Chelveston-cum-Caldecott Parish Council, 2016). The referendum in 2017 registered a turnout of 55 per cent of electors, with an 88 per cent vote in favour of the final plan.

These three technologies of enrolment enacted a public as a unitary constituency and resolved the problem of house-building by bringing housing into the collective identity they constructed; they made it a member of the neighbourhood. In other words, the resolution of the problem of housing was to make housing neighbourly. As a new neighbour housing makes its own associations that cannot be cocooned in a collective settlement. The potential for alternative publics, new attachments and preferences to arise from the direct democracy of neighbourhood planning is the subject of the next section. 


\section{Plural publics and their housing issues}

Michel Callon's (1986) celebrated theory of translation presents the democratic process as a practice of displacement through which a particular definition of the issue is adopted. Once the issue is defined, the interests of participants are aligned through a strategy of enrolment. In the final stage of displacement, a collective identity is established which presents an apparent consensus view and signals that participants have accepted their enrolment. Callon (1986: 223) emphasises the fragility of this moment of resolution and uses the idea of translation to affirm the continuity of displacement; agreement is not the end point of democracy but a temporary halt in the democratic process.

The democratic processes enlisted to resolve housing allocations in neighbourhood plans are 'multiply productive' (Chilvers \& Kearnes, 2016b: 40). The enrolment technologies of elicitation, deliberation, and procedural majoritarianism may enact a stable referent, but they also provide opportunities for participants to rescript the terms of the settlement, and to demonstrate in their turn new attachments to housing as an object of concern (Marres, 2007). With its promise of individual choice, the referendum campaign offers to widen the debate beyond the managed enrolment strategies of neighbourhood plan steering groups and open up antagonisms obscured by the claim of common cause (Young, 2000: 118). Interests cannot always be reconciled, and the referendum exposes the fractures that escape agreement (Mansbridge, 1996; Young, 2001). It gives legitimacy to individual attachments and offers technologies of enrolment to all, potentially enabling different publics to assemble and articulate their preferences (Qvortrup, 2005).

In one of the first referendums to take place in neighbourhood planning, in Thame, a town of 11,000 people in South Oxfordshire, a campaign emerged in opposition to the allocation of housing sites. 'Objections were made at the hearing, letters were written to the local press and calls were also made to reopen the referendum in attempts to overturn these allocations' (Brownill, 2017: 157). In the neighbourhood plan 
referendum in Holbeck, Leeds, an inner-city community of 5000 people, a local nationalist group campaigned vociferously for a 'no' vote and the ballot became a proxy for wider political divisions (Leeds City Council, 2018). The emergence of conflict over housing site allocations in neighbourhood plan referendums has been presented in the literature in normative terms as a failure of the democratisation of planning (Lord, Mair, Sturzaker \& Jones, 2017; Sturzaker \& Gordon, 2017). If we understand democracy as a practice of displacement through which temporary resolutions are imposed, reaching agreement appears of transitory importance. The hallmark of democracy is no longer how well it contains disagreement but instead the extent to which it allows the issues to be opened up for public debate (Marres, 2005a). The following study of a neighbourhood plan referendum demonstrates the failure of displacement and the continuance of contention.

The neighbourhood plan for the village of Overton, with a population of 4,315 , near Basingstoke in Hampshire, was launched in 2014 with a series of public assemblies attracting over 300 people, and 600 returned questionnaires. Two exhibitions were held to demonstrate proposals for housing site allocations to accommodate the minimum 150 homes required by planning policy. Nearly 250 people attended and were asked by the organisers to choose the criteria for the selection of final housing sites. This selection 'confirmed that residents placed the highest value on small sites phased over the plan period and choosing sites with the least possible adverse impact on the landscape' (Overton Parish Council, 2015: 9). The allocation of housing sites had to meet statutory planning requirements for viability and sustainability to ensure the selection would withstand external examination and challenge by developers (Bradley 2018; Parker, Lynn \& Wargent, 2017). In this screening process, 'it was not possible to satisfy the public preference for small sites entirely' (Overton Parish Council, 2015: 9) and, due to the constraints of national policy, several large sites were included. A further Site Selection Open Day in early 2015 was attended by over 400 residents who were asked to review three 'scenarios' of housing sites and rank them in order of preference. Scenario A, which included two large housing sites, was then incorporated in the plan. The statutory consultation on the pre-submission plan 
received 263 written responses from residents with 205 in full support. Acting on feedback the steering group made 14 changes to the wording of policies and removed two small sites from the plan, but complaints about the large sites in Scenario A were not upheld since they were judged to be expressions of individual material interest from residents immediately affected by the development (Overton Parish Council, 2015).

During the referendum campaign in 2016, a Vote No to Overton Neighbourhood Plan group emerged. The protest group argued that there had been no opportunity to raise objections to the housing sites and maintained the plan would lead to unwanted housing growth (comment in Yes4Overton, 2016). Further protests were raised in a leaflet titled Overton Neighbourhood Plan Reality Check. A Yes for Overton campaign issued a counter leaflet, and this prompted written corrections by Basingstoke and Deane planning authority. Specifically, the local authority pointed out that a petition against the inclusion of one housing site signed by 249 residents had not been included in the count of written objections to the neighbourhood plan and had not resulted in any revisions to the allocated sites (Basingstoke and Dean Borough Council, 2015). The turnout for Overton neighbourhood plan referendum, which coincided with the vote on the UK leaving the European Union, was the highest in the country with 71 per cent of the electorate, over 2000 people, voting; the narrow majority in favour of the plan was 53 per cent (Geoghegan, 2016). A local councillor commented: 'The whole subject of housing is emotive, but I don't want to see my community divided, neighbour against neighbour, as they have been' (quoted in Wilson, 2016).

This case study has been included at length to demonstrate the proliferation of contention that resulted from the failure of displacement in the Overton neighbourhood planning process. The final choice of housing sites was framed by the constraints of national planning policy and, once the question of site allocation was deemed settled, the steering group believed it could close off debate to enact a consensual collective and safely marginalise those whose continuing opposition was motivated only by their immediate material interest. Democratic debate overspilled 
into the referendum campaign as those individuals expressing personal preferences over the choice of housing sites endeavoured to marshal support and enrol their own Overton public. It is worth noting that almost four times as many residents took part in the referendum than participated in the earlier consultations, and that, while 249 people initially signed a petition against the housing sites, nearly 1000 opposed the sites at the ballot box. This suggests the mobilisation of support by those with direct attachments to the issues and the formation of new preferences in the referendum campaign. The neighbourhood plan became a demonstration of housing as an object of democratisation, but not agreement. It expanded the boundaries of public participation, and rendered the neighbourhood an arena of contestation, generating lasting antagonism.

'To open an issue up for public involvement requires the active displacement of issues, to sites hospitable to their articulation as objects of democratic politics' argued the theorist Noortje Marres (2005a: 140). In neighbourhood planning we see the issue of housing development planning opened up to public debate as an object of concern. In most cases the neighbourhood plan successfully resolved the issue by displacing it onto new policies that rendered housing, in a particular form and location, acceptable to an agreed collective neighbourhood identity. In this process, the assumptions of the market model of housing delivery were challenged. While the calculative technologies that establish housing targets were excluded from this debate by policy design, questions of the location of new house-building, its affordability, delivery, quality, design and relation to local need were rendered public issues, and, in their turn, these issues enacted a democratic public. Housing policies in the Overton plan prioritised local need, a mix of dwelling types and affordability, and attempted to influence the quality, scale and phasing of development. They were, therefore, typical of the particular approach to housing supply taken by neighbourhood plans (Bradley \& Sparling, 2017). Agreement on the housing allocation sites in Overton, if seen as evidence of successful displacement and quiescence, is not necessarily an indicator of democratic legitimacy. The continuation of dissension and antagonism is evidence that publics and their interests are engaged, and that issues are open for debate. 


\section{Conclusion}

The exclusion of self-selecting and informed publics from engagement in decisions in housing development planning is justified in reference to their material interest in the issue. The view expressed incessantly within the planning profession, supported to a more limited extent in the literature, is that these publics are motivated by the potential impact of development on the locational value of their property, and by their individual attachments to other assets that new house-building might adversely affect. One corrective response to this perspective is to stress the more principled and less immediately material concerns of these publics. An emerging literature presents them as the representatives of environmental and social causes who articulate a competing definition of the public good. This paper has taken a different approach, drawing on the work of political philosophers in Science and Technology Studies and actor-network theory. The paper foregrounds the role of issues as occasions for political democracy. Issues enact publics who are adversely caught up in them, and it is the issues, the publics they enact, and the articulation of mutually exclusive attachments, that constitute the democratic process. The pursuit of democratic legitimacy, then, does not reside solely in the architecture of representative democracy, or in the achievement of an idealised consensus on the public good. It can be found in a democratic process that confronts issues and opens them up to public debate. The innocence or otherwise of publics is not the focus of concern. What matters is the extent to which these publics are able to articulate their competing interests, and either reach a negotiated settlement, or continue to contest the issue.

The use of direct democracy in the policy of neighbourhood planning in England opened up the issue of housing development to public debate within binding constraints established by statutory regulation. The demonstration of housing as a matter of public concern in the neighbourhood plan was also the demonstration of a collective public with the ability to solve it. The paper charted the technologies of enrolment used by neighbourhood planning groups to identify publics and elicit 
agreement, the pursuit by participants of their exclusive material interests, and their acknowledgement, and in some cases, rejection of the validity of attachments that excluded their own. In opening up the issue of housing development within the parameters of policy, neighbourhood plans challenged the linkage between housing supply and a market model of delivery and began to question the technologies and exclusions that enforce consensus in housing development planning. In adopting an issue-based approach to participation they devised solutions to housing supply problems that were sensitive to local needs and that secured majority consent. Resolution of the issue, however, is not the end point of democracy in this study. The democratisation of planning for housing development is evidenced in the possibility of continuing dissension, in the expansion of the boundaries of participation, when publics and their interests are engaged, and issues are open for debate. This analysis of the use of direct democracy to allocate housing sites has resonance beyond its English case study for the wider literature on public participation and democratic engagement. It suggests policy makers and practitioners should abandon the fruitless search for an innocent public and recognise the legitimacy of one that is informed and directly implicated in the issues. Housing is a matter of concern that calls for open debate and the public articulation of mutually conflicting interests. Around that debate a more democratic society can be enrolled. 


\section{Sources}

Allmendinger, P. \& M. Tewdwr-Jones (2002) The Communicative Turn in Urban Planning: Unravelling Paradigmatic, Imperialistic and Moralistic Dimensions. Space \& Polity, 6, (1): 5-24

Arnstein, S. (1969) A Ladder of Citizen Participation. American Institute of Planners Journal, Vol. 35, No. 4: 216-224.

Bailey, N. (2017): Housing at the neighbourhood level: a review of the initial approaches to neighbourhood development plans under the Localism Act 2011 in England, Journal of Urbanism: International Research on Placemaking and Urban Sustainability, 10 (1) 1-15

Barry, A. (2001) Political machines: governing a technological society. London. The Athlone Press

Basingstoke and Dean Borough Council (2015) Factual update regarding the Overton Neighbourhood Plan. Basingstoke. Basingstoke and Dean Borough Council

Benhabib, S. (1996) Toward a Deliberative Model of Democratic Legitimacy. In: Benhabib, S. (Ed.) Democracy and difference: contesting the boundaries of the political. Princeton, N.J. Princeton University Press: 67-94

Bradley, Q. (2018) Neighbourhood planning and the production of spatial knowledge. Town Planning Review, 89 (1): 23-42

Bradley, Q (2017) Neighbourhood planning and the impact of place identity on housing development in England. Planning Theory \& Practice. Vol.18 (2): 233-248 Bradley, Q (2015) The political identities of neighbourhood planning in England. Space and Polity. Vol.19 (2): 97-109

Bradley, Q. (2014) The tenants' movement. London. Routledge Bradley, Q. \& Brownill, S. (2017) Reflections on neighbourhood planning: towards a progressive localism. In: Brownill, S. \& Q. Bradley (eds.) Localism and Neighbourhood Planning: power to the people? Bristol. Policy Press: 251-267

Bradley, Q. \& Sparling, W. (2016) The Impact of Neighbourhood Planning and Localism on House-building in England. Housing, Theory and Society, Vol. 34 (1): 106-118 
Bramley, G. (2018) Housing supply requirements across Great Britain for low-income households and homeless people. London. Crisis/National Housing Federation.

Brookfield, K. (2017) Getting involved in plan-making: Participation in neighbourhood planning in England. Environment and Planning C: Politics and Space. Vol. 35(3) 397416

Brownill, S. (2017) Assembling neighbourhoods: topologies of power and the reshaping of planning. In: Brownill, S. \& Q. Bradley (eds.) Localism and Neighbourhood Planning: power to the people? Bristol. Policy Press.

Brownill, S. \& L. Downing (2013) Neighbourhood plans - is an infrastructure of localism emerging. Town \& Country Planning. 82 (9): 372-376

Butler, J. (2010) Performative agency. Journal of Cultural Economy, 3 (2): 147-161, Callon, M. (1986) Some elements of a sociology of translation: domestication of the scallops and the fishermen of St. Brieuc Bay. In: Law, J. (ed.) Power, Action and Belief. London. Routledge

Callon, M., P. Lascoumes \& Y. Barthe (2011) Acting in an uncertain world: an essay on technical democracy. London. MIT Press

Campbell, H. \& R. Marshall (2000) Public Involvement and Planning: Looking beyond the One to the Many. International Planning Studies, 5 (3): 321-344

Chelveston-cum-Caldecott Parish Council (2016) Our village, our plan, our future. Chelveston-cum-Caldecott. Chelveston-cum-Caldecott Parish Council

Chilvers, J. \& M. Kearnes (2016a) Science, democracy and emergent publics. In: Chilvers, J. \& M. Kearnes (eds.) Remaking participation: science, environment and emergent publics. London. Routledge: 1-28

Chilvers, J. \& M. Kearnes (2016b) Participation in the making: rethinking public engagement in co-productionist terms. In: Chilvers, J. \& M. Kearnes (eds.) Remaking participation: science, environment and emergent publics. London. Routledge: 99-120 Chilvers, J. \& N. Longhurst (2016) Participation in transitition: reconceiving public engagement in energy transitions as co-produced, emergent and diverse. Journal of Environmental Policy \& Planning. Vol.18 (5): 585-607 
Cook, N., E.J. Taylor, J. Hurley (2013) At home with strategic planning: reconciling resident attachments to home with policies of residential densification. Australian Planner. Vol. 50 (2) 130-137

Croft, N., C. Loveday, E. Johnson \& J. Reeves (2016) The referendum question - does public participation affect neighbourhood plan turnouts and outcomes? Town \& Country Planning. Vol.85, 10: 422-430

DCLG (2011) Localism Bill: neighbourhood plans equalities impact assessment. London. Department of Communities \& Local Government.

DCLG (2012) National Planning Policy Framework. London. DCLG

Dear, M. (1992) Understanding and overcoming the NIMBY syndrome. Journal of the American Planning Association. Vol. 58, No.3:288-300

Dear, M. \& S. Taylor (1982) Not on our street. Community attitudes to mental health care. London. Pion.

Della Porta, D. (2013) Can democracy be saved? Participation, deliberation and social movements. Cambridge. Polity Press

Della Porta, D., F. O'Connor, M. Portos \& A.S. Ribas (2017) Social movements and referendums from below: direct democracy in the neoliberal crisis. Bristol. Policy Press. DeVerteuil, G. (2013) Where has NIMBY gone in urban social geography? Social and Cultural Geography. Vol.14, No. 6: 599-603

Devine-Wright, P. (2009) Rethinking NIMBYism: the role of place attachment and place identity in explaining place protective action. Journal of Community \& Applied Social Psychology. 19: 426-441

Dewey, J. (1927) The public and its problems. Athens, USA. Swallow Press / Ohio University Press

East Bergholt Parish Council (2016) East Bergholt Neighbourhood Plan: our village our future 2015 - 2030. East Bergholt, East Bergholt Parish Council

Ellis, G. (2004) Discourses of objection: towards an understanding of third-party rights in planning. Environment and Planning A. 36: 1549-1570

Fainstein, S. (2000) New Directions in Planning Theory. Urban Affairs Review. Vol. 35, No.4: 451-478 
Field, M. \& A. Layard (2017) Locating community-led housing within neighbourhood plans as a response to England's housing needs. Public Money \& Management. Vol. 32 (2): $105-112$

Fischel, W. A. (2004) An economic history of zoning and a cure for its exclusionary effects. Urban Studies, 41(2), 317-340.

Gallent, N. (2016), Investment, global capital and other drivers of England's housing crisis. Journal of Urban Regeneration and Renewal, 9: 122-38.

Gallent, N., D. Durrant \& P. Stirling (2018) Between the unimaginable and the unthinkable: pathways to and from England's housing crisis. Town Planning Review, 89 (2): $125-144$

Garcia-Espin, P., E. Ganuza \& S. de Marco (2017) Assemblies, referendums or consultations? Social representations of citizen participation. Revista Espanla de Investigaciones Sociologicas. No. 157: 45-64

Geoghegan, J. (2016) Why did a Hampshire neighbourhood plan generate more opposition than any other? Planning Resource. 2 September. Northampton, Haymarket Media Group.

Houtzager, P. \& A. G. Lavalle (2010) Civil Society's claims to political representation in Brazil. Studies in Comparative International Development, 45:1-29

Inch, A. (2012) Creating 'a generation of NIMBYs'? Interpreting the role of the state in managing the politics of urban development. Environment \& Planning C: government and policy, 30: 520-535

Irwin, A. (2006) The politics of talk: coming to terms with the 'new' scientific governance. Social Studies of Science. 36,2: 299-320

Kearns, A. \& M. Parkinson (2001) The Significance of Neighbourhood. Urban Studies. Vol. 38, No.12: 2103-2110

Latour, B. (2005a) From Realpolitik to Dingpolitik, or how to make things public. In: Latour, B. \& P. Weibel (eds.) Making things public: atmospheres of democracy. London, MIT Press

Latour, B. (2005b) Reassembling the social: an introduction to actor-network theory. Oxford. Oxford University Press. 
Leeds City Council (2018) Press Notice to correct inaccuracies in material published by William Palfreman in relation to the Holbeck Neighbourhood Plan Referendum. Leeds, Leeds City Council

Leino, H. \& M. Laine (2011) Do matters of concern matter? Bringing issues back to participation. Planning Theory. Vol. 11 (1): 89-103

Lezaun, J. (2007) A market of opinions: the political epistemology of focus groups. The Sociological Review, 55, Issue Supplement: 130-151

Lezaun, J. \& L. Soneryd (2007) Consulting citizens: technologies of elicitation and the mobility of publics. Public Understanding of Science. 16: 279-297

Lichfields (2018) Local choices? Housing delivery through Neighbourhood Plans. London. Lichfields

Lord, A., M. Mair, J. Sturzaker, \& P. Jones (2017) 'The planners' dream goes wrong?' Questioning citizen-centred planning, Local Government Studies, 43:3, 344-363

Lupia, A. \& J. Matsusaka (2004) Direct democracy: new approaches to old questions. Annual Review of Political Science. No 7:463-82

McClymont, K. \& P. O'Hare (2008) "We're not NIMBYs" Contrasting local protest groups with idealised conceptions of sustainable communities. Local Environment. Vol.13 (4): 321-335

McGuinness, D. \& C. Ludwig (2017) Developing a neighbourhood plan: stories from 'community-led' planning pathfinders. In: Brownill, S. \& Q. Bradley (Eds.) Localism and Neighbourhood Planning: power to the people? Bristol. Policy Press.

Mansbridge, J. (2003) Rethinking representation. The American Political Science Review, Vol. 97, No. 4 (pp. 515-528

Mansbridge, J. (1996) Using Power/Fighting Power: the polity. In: Benhabib, S.(Ed.) Democracy and difference: contesting the boundaries of the political. Princeton, N.J. Princeton University Press: 46-66

Marres, N. (2007) The issues deserve more credit: pragmatist contributions to the study of public involvement in controversy. Social Studies of Science. 37,5: 759-780 Marres, N. (2005a). No issue, no public: democratic deficits after the displacement of politics. Amsterdam. Ipskamp Printpartners 
Marres, N. (2005b) Issues spark a public into being: a key nut often forgotten point of the Lippmann-Dewey debate. In: Latour, B. \& P. Weibel (eds.) Making things public: atmospheres of democracy. London, MIT Press

Marres, N. \& J. Lezaun (2011) Materials and devices of the public: an introduction. Economy \& Society. 40, 4: 489-509

Matthews, P., G. Bramley, \& A. Hastings (2015) Homo Economicus in a Big Society: understanding middle-class activism and NIMBYism towards new housing developments. Housing Theory \& Society. 32 (1): 54-72

Metzger, J., P. Allmendinger \& S. Oosterlynck (2015) Planning against the political: democratic deficits in European territorial governance. London. Routledge

Metzger, J., L. Soneryd, \& S. Linke (2017) The legitimization of concern: a flexible framework for investigating the enactment of stakeholders in environmental planning and governance processes. Environment and Planning A, 49 (1): 2517-2535

Mountain, C. (2015) Neighbourhood Planning: progress on housing delivery. London. DCLG Neighbourhood Planning Team.

Overton Parish Council (2015) Overton Neighbourhood Development Plan. Overton. Overton Parish Council

Parker, G. \& M. Wargent (2017) Participant experience of neighbourhood planning in England. Working papers in real estate and planning 01/17. Reading. Henley Business School, University of Reading.

Parker, G., Lynn, T. and Wargent, M. (2017) Contestation and conservatism in neighbourhood planning in England: reconciling agonism and collaboration? Planning Theory \& Practice, 18:3, 446-465

Parker, G., T. Lynne, M. Wargent \& Locality (2014) User experience of neighbourhood planning in England research. Reading. University of Reading.

Pateman, C. (1970) Participation and democratic theory. London. Cambridge University Press

Qvortrup, M. (2015) Power to the People! But How? The Different Uses of Referendums Around the World. Political Studies Review. Vol. 13: 37-45

Qvortrup, M. (2005) A comparative study of referendums: government by the people. Mancester. Manchester University Press 
Ruming, K., D. Houston \& M. Amati (2012) Multiple suburban publics: rethinking community opposition to consolidation in Sydney. Geographical Research. Vol. 50 (4): $421-435$

St. Minver Parishes (2017) St Minver Parishes NDP Consultation Statement. St. Minver, Cornwall, St. Minver Parishes

Saward, M. (2010) The representative claim. Oxford. Oxford University Press

Sherborne St. John Parish Council (2017) Sherborne St. John Neighbourhood Plan 2011-2029. Sherborne St. John, Sherborne St. John Parish Council

Spivak, G. C. (1988) Can the Subaltern Speak? In: Nelso, Cary \& Lawrence Grossberg (eds.) Marxism \& the Interpretation of Culture. Chicago, University of Illinois Press Stanier, R. (2014) Local Heroes: Neighbourhood Planning in Practice. Journal of Planning and Environment Law. Issue 13. Thomson Reuters (Professional) UK Limited Sturzaker, J. (2010) The exercise of power to limit the development of new housing in the English countryside. Environment and Planning A. Vol. 42: 1001 - 1016 Sturzaker, J. (2011) Can Community Empowerment Reduce Opposition to Housing? Evidence from Rural England, Planning Practice \& Research, 26 (5): 555-570 Sturzaker, J. \& M. Gordon (2017) Democratic tensions in decentralised planning rhetoric, legislation and reality in England. Environment and Planning C: Politics and Space. p.2399654417697316.

Sturzaker, J. \& D. Shaw (2015) Localism in practice: lessons from a pioneer neighbourhood plan in England. Town Planning Review, 86 (5): 587-608 Sturzaker, J. \& M. Shucksmith (2011) Planning for housing in rural England: discursive power and spatial exclusion. Town Planning Review, 82 (2) 169-193

Tattenhall \& District (2013) Tattenhall Neighbourhood Development Plan. Cheshire. Tattenhall Parish Council

Taylor, E. (2013) Do house values influence resistance to development? A spatial analysis of planning objection and appeals in Melbourne. Urban Policy and Research, 31(1):

Taylor, E. Cook N. \& Hurley, J. (2016) Do objections count? Estimating the influence of residents on housing development assessment in Melbourne. Urban Policy and Research, doi 10.1080/08111146.2015.1081845 
Tierney, S. (2015) Reclaiming Politics: Popular Democracy in Britain after the Scottish Referendum. The Political Quarterly, Vol. 86, No. 2: 226-23

Uttoxeter Town Council (2016) Part 2 Consultation Report: Uttoxeter Neighbourhood Plan. Appendix 2 Frequently Asked Questions. Uttoxeter. Uttoxeter Town Council Vigar, G., S. Gunn \& E. Brooks (2017) Governing our neighbours: participation and conflict in neighbourhood planning. Town Planning Review. Vol. 88, 4: 423-442

Wargent, M. and G. Parker (2018) Re-imagining neighbourhood governance: the future of neighbourhood planning in England. Town Planning Review, 89 (4): 299-402 Wendling, K. (1997) Unavoidable Inequalities: Some Implications for Participatory Democratic Theory. Social Theory \& Practice. 23(2):161-179

Wilson, C. (2016) Approved Overton housing plan 'flawed from start to finish'. Basingstoke Observer. July 29. [Internet] Available at: http//www.basingstokeobserver.co.uk. Accessed 11 March 2018

Wolsink, M. (2006) Invalid theory impedes our understanding: a critique on the persistence of the language of NIMBY. Transactions of the Institute of British Geographers. Vol.31: 85-91

Wynne, B. (2007) Public participation in science and technology: performing and obscuring a political-conceptual category mistake. East Asian Science, Technology and Society: an international journal. 1(1): 1-13

Yes4Overton (2016) Facebook Page. Comment by EM Kei, 13 June. [Internet] Available at: http://www.facebook.co.uk. Accessed 11 March 2018.

Young, I.M. (2000) Inclusion and Democracy. Oxford. Oxford University Press Young, I.M. (2001) Activist Challenges to Deliberative Democracy. Political Theory. Vol.29, 5: 670-690

Zakhour, S. \& J. Metzger (2018) Placing the action in context: contrasting publiccentred and institutional understandings of democratic planning politics. Planning Theory \& Practice, 19 (3): 345-362 